\title{
AN AMPEROMETRIC BIOSENSOR FOR HG(II) BASED ON UREASE/ALGINATE-CHITOSAN MEMBRANE MODIFIED SCREEN PRINTED CARBON ELECTRODE
}

\author{
Rochmad Kris Sanjaya ${ }^{1}$, Nurul Ismillayli ${ }^{2}$, Dhony Hermanto ${ }^{2 *}$, \\ ${ }^{1}$ Program Studi Farmasi, Fakultas Ilmu Kesehatan, Universitas Kadiri, Kediri-Jawa Timur, Indonesia \\ ${ }^{2}$ Program Studi Kimia, Fakultas MIPA, Universitas Mataram, Mataram-Nusa Tenggara Barat, Indonesia \\ *Email: dhony.hermanto@ unram.ac.id
}

Diterima: 28 Agustus 2019. Disetujui: 28 September 2019. Dipublikasikan: 30 September 2019

\begin{abstract}
A screen-printed three-electrode system is fabricated to prepare a novel screen-printed biosensor for rapid determination of $\mathrm{Hg}$ (II) in aqueous solution. The amperometric biosensor is prepared by entrapping urease in alginate-chitosan membrane to modify the screen-printed carbon electrode. The urease/alginate-chitosan membrane for $\mathrm{Hg}$ (II) had optimum measurement conditions at work potential of $-0.15 \mathrm{~V}$, pH of 7 , urea concentration of 75 $\mathrm{mM}$, response time of 8 seconds, inhibition time of 7 minutes and temperature of $25^{\circ} \mathrm{C}$. The resulted biosensor characteristic were found to have the range concentration of $\mathrm{Hg}$ (II) ion between $40-90 \mathrm{ppb}$ with the detection limit $\mathrm{I}_{10 \%}$ was $66.45 \mathrm{ppb}$, the coefficient of variance $(\mathrm{Cv})$ was $0.8 \%$, and reactivation was 5 times reuse.
\end{abstract}

Keywords : Amperometric biosensor, Urease/alginate-chitosan membrane, Screen-printed carbon electrode

Abstrak: Sistem screen-printed tiga elektroda dibuat sebagai screen-printed biosensor dalam penentuan $\mathrm{Hg}(\mathrm{II})$ dalam larutan secara langsung. Biosensor amperometri dipreparasi dengan penjerapan urease pada membran alginat-kitosan untuk memodifikasi screen-printed elektroda karbon. Pada urease/alginate-chitosan untuk penentuan $\mathrm{Hg}(\mathrm{II})$ memiliki kondisi optimum pengukuran pada potensial kerja $-0,15 \mathrm{~V}, \mathrm{pH} 7$, konsentrasi urea 75 $\mathrm{mM}$, waktu respon 8 detik, waktu inhibisi 7 menit dan suhu $25{ }^{\circ} \mathrm{C}$. Hasil karakterisasi biosensornya yaitu range konsentrasi ion $\mathrm{Hg}(\mathrm{II})$ antara 40-90 ppb dengan batas deteksi $\mathrm{I}_{10 \%}$ adalah $66.45 \mathrm{ppb}$ dan koefisien variansi (Kv) sebesar $0,8 \%$, serta reaktivasi pemakaian ulang sebanyak 5 kali.

Kata Kunci : Biosensor amperometri, Urease/alginat-kitosan membran, Screen-printed elektroda karbon

\section{PENDAHULUAN}

Merkuri (Hg) merupakan salah satu jenis logam berat yang berpotensi sebagai pencemar lingkungan dan sangat berbahaya bagi kesehatan manusia. Informasi yang cepat dan akurat mengenai kandungan $\mathrm{Hg}$ di lingkungan merupakan hal sangat penting. Beberapa metode analisis yang digunakan untuk penentuan merkuri dalam sampel lingkungan dan biologi, seperti spektrometri serapan atom (AAS) [1], plasma induktif yang digabungkan dengan spektrometri massa (ICP-MS) [2] serta elektrokimia [3], telah dikembangkan untuk mendeteksi merkuri di lingkungan. Metode ini memiliki keterbatasan, seperti membutuhkan waktu yang lama, menggunakan sejumlah besar reagen kimia dan peralatan mahal, membutuhkan operator yang terlatih dan tidak dapat digunakan untuk analisis lapangan [4]. Teknologi baru diperlukan yang sederhana dengan kemampuan tinggi untuk pemantauan merkuri dengan respon yang cepat, tidak mahal dan dapat dilakukan analisis di tempat. Biosensor merupakan alternatif perangkat yang bisa dikembangkan untuk kebutuhan ini, dengan menggabungkan selektivitas dan sensitivitas sistem biologis dalam perangkat kecil untuk penentuan merkuri dalam sampel lingkungan yang tercemar [5].

Sebagian besar biosensor untuk mendeteksi ion logam dirancang melalui penghambatan enzim. Metode ini umumnya memerlukan pengukuran kuantitatif aktivitas enzim atau persentase inhibisi sebagai dasar metode analisis. Telah dilaporkan beberapa contoh enzim yang digunakan untuk deteksi $\mathrm{Hg}(\mathrm{II})$, seperti enzim peroksidase, xantine oksidase, glukosa oksidase dan urease [6]. Penentuan ion $\mathrm{Hg}$ (II) dengan menggunakan biosensor optik berbasis immobilisasi enzim urease (hidrolase) telah dilakukan oleh Kuswandi [7]. Enzim yang sama digunakan dalam pengembangan biosensor enzimatik untuk pengukuran $\mathrm{Hg}$ (II) berdasarkan inhibisi pada aktivitas urease yang diimobilisasikan pada matriks poly(vinylferrocenium) secara amperometri [8].

Penggunaan poly(vinylferrocenium) sebagai matriks pendukung imobilisasi urease memiliki keterbatasan karena kurang ramah lingkungan, mahal dan membutuhkan preparasi rumit, serta memiliki batas deteksi yang cukup tinggi. Oleh karena itu, dibutuhkan matriks pendukung yang lebih baik dalam menunjang performa biosensor. Membran alginatkitosan sebagai kompleks polielektrolit [9] bukanlah sekedar bahan pendukung untuk imobilisasi urease, melainkan matriks polimer dengan karakteristik yang unik seperti perm-selektivitas dan kemampuan untuk menjebak molekul kecil sehingga sensitivitas, selektivitas dan stabilitas elektroda termodifikasi meningkat [10]. Pada penelitian ini digunakan membran alginat-kitosan sebagai matriks pendukung imobilisasi urease dan dimoifikasi dengan Screenprinted elektroda karbon. 


\section{METODE PENELITIAN}

Urease yang digunakan dalam preparasi biosensor adalah E.C. 3.5.1.5. dari jack beans (Type III, U1500) $272 \mathrm{u} / \mathrm{g}$ dan disimpan pada $4{ }^{\circ} \mathrm{C}$. Sodium alginat dengan 300-400 cp dari alga coklat dan kitosan dengan $95 \%$ deasetilasi dari cangkang kepiting produksi Sigma (St.Lois, USA). $\mathrm{HCl}$ (37\%), $\mathrm{CH}_{3} \mathrm{COOH}$ glacial $(98 \%), \mathrm{NaOH}$ dan $\mathrm{KH}_{2} \mathrm{PO}_{4}$ dari Merck (Germany). Larutan stock urea $(1000 \mu \mathrm{g} / \mathrm{mL})$ dipreparasi dalam larutan. Larutan $\mathrm{Hg}\left(\mathrm{NO}_{3}\right)_{2}, \mathrm{AgNO}_{3}$, $\mathrm{CdCl}_{2}, \quad \mathrm{CuSO}_{4}, \quad \mathrm{~Pb}\left(\mathrm{NO}_{3}\right)_{2}$ dipreparasi dengan melarutkan garam dalam larutan. Prosedur electrochemical ditentukan dengan PalmSens portable potentiostat/galvanostat, dengan PSTrace program dan asesoris (PalmSens ${ }^{\circledR}$ Instruments BV, 3992 BZ Houten, the Netherlands). Portable potentiostat dihubungkan computer dengan software PS Trace 4.2 untuk akuisisi data dan control eksperimen. $\mathrm{pH}$ meter model IM-20E (TOA Electronic Ltd.) digunakan dalam pengukuran $\mathrm{pH}$.

Sintesis membran alginat-kitosan dilakukan sesuai Hermanto dkk. [9]. Polimerisasi kitosan diperoleh dengan mendispersikan $1 \mathrm{~g}$ kitosan ke dalam $25 \mathrm{~mL}$ akuades kemudian dilarutkan dengan menambahkan $5 \mathrm{~mL}$ asam asetat glasial sambil diaduk dengan menggunakan pengaduk magnit sehingga terbentuk campuran homogen. Polimerisasi alginat diperoleh dengan melarutkan $1 \mathrm{~g}$ alginat dalam $25 \mathrm{~mL}$ aquadest. Kedua larutan dibiarkan satu malam. Kedua larutan polimer kemudian dicampur dengan rasio massa 1:1 dan ditambahkan $2 \mathrm{~mL} \mathrm{HCl} 32 \%$. Selanjutnya ditambahkan larutan $\mathrm{NaOH} 10 \%$ (w/v) sampai diperoleh $\mathrm{pH}=5,28$. Polimer terbentuk adalah hidrosol. Membran digunakan sebagai pendukung (solid support) imobilisasi untuk enzim. Urease yang digunakan berjumlah 46,24 $\mathrm{U}$ yang diperoleh dengan melarutkan $1,7 \quad \mathrm{mg}$ urease dalam $1,5 \mathrm{~mL}$ buffer fosfat $\mathrm{pH} 7,4$ dan disimpan pada $4{ }^{\circ} \mathrm{C}$.

Membran alginat-kitosan untuk biosensor amperometri dipreparasi dengan mencampurkan kedua polimer hidrosol. Hidrosol polimer diaduk dengan pengaduk magnit selama 4 jam kemudian dilakukan imobilisasi urease. Pada tahap ini ditambahkan $1 \mathrm{~mL}$ buffer fosfat $\mathrm{pH}$ 6,5 dan 46,24 U urease distirer selama \pm 10 menit, dan selama imobilisasi berlangsung suhu dijaga pada $4{ }^{\circ} \mathrm{C}$. Hidrosol yang terbentuk kemudian coating pada screen printed electrode (SPE) dan letakkan di atas plat kaca, kemudian dikeringkan suhu $27{ }^{\circ} \mathrm{C}$ selama 72 jam Membran alginat-kitosan dengan urease terimobil di dalamnya setelah terbentuk direndam larutan enzim 24 jam.

Membran alginat-kitosan dengan urease terimobil di dalamnya pada biosensor amperometri coating pada permukaan electroda. Pengukuran $\mathrm{Hg}$ (II) dengan berbagai variasi konsentrasi menggunakan biosensor amperometri. Larutan $\mathrm{Hg}(\mathrm{II})$ dengan berbagai variasi konsentrasi dibuat dengan melarutkan larutan $\mathrm{Hg}(\mathrm{II})$ standar $(1000 \mathrm{mg} / \mathrm{L})$ dengan larutan buffer fosfat. Pengukuran respon sensor dari biosensor amperometri oleh PS Trace 4.2.

\section{HASIL DAN PEMBAHASAN}

Biosensor elektrokimia telah digunakan secara langsung untuk monitoring logam berat beradasarkan inhibisi enzim. Pada metode ini dibutuhkan tranduser yang sesuai untuk penentuan kuantitatif aktivitas enzim atau persen inhibisi. Persamaannya ditunjukkan pada persamaan berikut:

$$
\mathrm{E}_{\mathrm{oks}}+\mathrm{S} \leftrightarrow\left[\mathrm{E}_{\mathrm{oks}} \mathrm{S}\right] \rightarrow \mathrm{E}_{\mathrm{red}}+\mathrm{P}
$$

Mekanisme biosensor amperometri berdasarkan inhibisi urease untuk mendeteksi ion $\mathrm{Hg}$ (II) dalam larutan. Urease memutus ikatan karbonnitrogen pada ikatan amida dari urea menghasilkan $\mathrm{CO}_{2}, \mathrm{NH}_{3}$, dan air pada kondisi enzim teroksidasi melalui pembentukan intermediet ikatan oksida enzim-substrat.

Pembentukan produk hidrolisis urea diikuti dengan pembentukan kembali enzim dalam bentuk reduksinya. Enzim redoks terbentuk sebagai hasil dari reaksi reduksi dan oksidasi enzim seperti pada persamaan dibawah yang menunjukkan elektron dihasilkan terdeteksi oleh transduser elektrokimia.

$$
\mathrm{E}_{\mathrm{red}} \rightarrow \mathrm{E}_{\mathrm{oks}}+\mathrm{e}^{-}
$$

Selanjutnya, pengukuran inhibisi dilakukan dengan mengalirkan ion $\mathrm{Hg}(\mathrm{II})$. Pada mekanisme biokimia, inhibisi urease oleh ion $\mathrm{Hg}(\mathrm{II})$ dihasilkan dari ikatan ion $\mathrm{Hg}(\mathrm{II})$-merkaptida dengan gugus sulfidril (-SH) dari urease. Gugus sulfidril yang berinterkasi dengan $\mathrm{Hg}(\mathrm{II})$ merupakan bagian dari residu cys592 yang terletak pada mobile flap sisi aktif enz im. Inhibisi oleh ion $\mathrm{Hg}$ (II) pada aktivitas urease menyebabkan urea terhidrolisis dengan laju yang lebih lambat bahkan dapat menghilangkan aktivitas enzim. Perubahan elektrokatalitik sebelum dan setelah inhibisi memberikan informasi adanya sejumlah ion $\mathrm{Hg}$ (II) sehingga metode ini dapat digunakan sebagai alat elektrokimia pada pendeteksian ion $\mathrm{Hg}$ (II) dalam sistem.

Penggunaan enzim redoks diamati secara amperometri menggunakan tiga elektrode screenprinted (disposable electrode) dan arus oksidasi dikorelasikan dengan aktivitas urease. Logam berat dalam sampel menginhibisi aktivitas urease, menyebabkan produksi $\mathrm{NH}_{4}{ }^{+}$lebih lambat dan oksidasi enzim berkurang. Pengurangan aktivitas karena adanya logam berat sebanding dengan jumlah logam berat dalam sampel.

Optimasi parameter eksperimental merupakan langkah penting dalam karakteristik analitis kinerja biosensor $\mathrm{Hg}$ (II) amperometri. Tabel 1 menunjukkan beberapa parameter biosensor $\mathrm{Hg}$ (II) amperometri yang diteliti dan nilai optimumnya [11].

Tabel 1. Optimasi parameter biosensor amperometri

\begin{tabular}{lcc}
\hline \multicolumn{1}{c}{ Parameter } & Range & Optimum \\
\hline Waktu respon (detik) & $0-20$ & 4 \\
Potential kerja (V) & $-0.5-0$ & -0.15 \\
pH & $5-8$ & 7 \\
Konsentrasi Substrat (mg/L) & $50-100$ & 75 \\
Temperatur $\left({ }^{\circ} \mathrm{C}\right)$ & $20-35$ & 25 \\
Waktu inhibisi (menit) & $4-8$ & 7 \\
\hline
\end{tabular}


Waktu yang dibutuhkan biosensor untuk memperoleh intensitas sinyal dan kemudian konstan selama beberapa waktu. Penentuan waktu respon dalam penelitian ini dilakukan dengan variasi waktu antar 0 menit sampai 20 detik dalam larutan urea (75 $\mathrm{mM}$ ), pH 6 (larutan buffer fosfat) menggunakan 50 $\mathrm{ppb}$ ion $\mathrm{Hg}(\mathrm{II})$. Hasil pengukuran waktu respon didapatkan bahwa pada $\mathrm{t}=4$ detik dipilih sebagai waktu respon untuk biosensor. Pemilihan waktu 4 detik sebagai waktu respon, karena pada $t=4$ detik ini urease sudah jenuh oleh urea.

Efek potensial kerja pada arus dalam keadaan mapan diukur dengan rentang potensial dari 0 hingga $-0,5 \mathrm{~V}$ dalam larutan urea $(75 \mathrm{mM}), \mathrm{pH} 6$ (larutan buffer fosfat) menggunakan $50 \mathrm{ppb}$ ion $\mathrm{Hg}(\mathrm{II})$. Arus steady-state dari proses reduksi elektrokatalitik ion $\mathrm{Hg}$ (II) meningkat dengan cepat dari $-0,5$ hingga $-0,15 \mathrm{~V}$ tetapi lebih lambat akibat perubahan yang lebih besar dalam potensi kerja $-0,15$ hingga $0 \mathrm{~V}$. Perubahan kenaikan saat ini sebagai akibat dari aktivitas elektrokatalitik karena penghambatan ion $\mathrm{Hg}$ (II) digunakan sebagai dasar untuk pengukuran. Selain itu, potensi kerja yang rendah mengarah pada pengaruh spesies elektroaktif. Oleh karena itu, $-0,15 \mathrm{~V}$ dipilih sebagai potensial kerja pada pengukuran biosensor amperometri.

Salah satu aspek penting dalam menentukan kondisi optimum biosensor adalah pemilihan $\mathrm{pH}$. Perubahan $\mathrm{pH}$ adalah efek dari interaksi analit, yang pada gilirannya perubahan dalam lingkungan $\mathrm{pH}$ dapat ditunjukkan oleh respon sensor secara sensitif. Pengaruh matriks dan gangguan elektrokatalitik lainnya dapat diminimalkan dengan menggunakan larutan buffer. Reaksi hidrolisis urea sebagai dasar pengukuran biosensor tergantung pada nilai $\mathrm{pH}$. Stabilitas respon sensor dengan perubahan $\mathrm{pH}$ dapat dikontrol. Pengaruh $\mathrm{pH}$ pada arus dalam keadaan mantap dengan variasi $\mathrm{pH}$ dalam rentang $\mathrm{pH}$ dari 5 hingga 8 dalam larutan buffer fosfat dengan $75 \mathrm{mM}$ solusi urea. Larutan buffer fosfat pada $\mathrm{pH} \quad 7$ ditemukan menjadi optimal dan digunakan sebagai $\mathrm{pH}$ optimum dalam reaksi enzimatik untuk pengukuran lebih lanjut.

Reaksi enzimatik akan berlangsung efektif ketika konsentrasi substrat sebanding dengan nilai $\mathrm{K}_{\mathrm{M}}$ enzim. Oleh karena itu, diperlukan optimalisasi konsentrasi substrat untuk mendapatkan hasil yang teramati dengan jelas. Konsentrasi substrat optimum (urea) dalam penelitian ini ditentukan dengan memvariasikan konsentrasi urea antara 50 hingga 100 $\mathrm{mM}$ dengan konsentrasi tambahan sebesar $5 \mathrm{mM}$. Pada kondisi tersebut, konsentrasi $75 \mathrm{mM}$ ditemukan optimal untuk konsentrasi urea. Konsentrasi ini digunakan untuk pengukuran biosensor amperometri berdasarkan pada inhibisi urea oleh ion $\mathrm{Hg}$ (II).

Suhu kerja dari reaksi enzimatik mempengaruhi perubahan dari sinyal kosong dan penghambatan. Sensor merespon perubahan suhu, dalam penelitian ini suhu divariasi 20 hingga $30{ }^{\circ} \mathrm{C}$. Itu terlihat bahwa suhu $25{ }^{\circ} \mathrm{C}$ adalah suhu optimum dari reaksi enzimatik ini. Respon arus biosensor terhadap suhu menunjukkan pada suhu yang lebih tinggi terjadi penurunan respon, hal ini disebabkan aktivitas enzim menurun akibat denaturasi molekul enzim yang terimobil. Suhu $25{ }^{\circ} \mathrm{C}$ kemudian dipilih sebagai suhu kerja untuk pengukuran amperometri lebih lanjut dari biosensor $\mathrm{Hg}(\mathrm{II})$.

Optimasi waktu inhibisi dimaksudkan untuk memberikan ion $\mathrm{Hg}$ (II) cukup waktu untuk mengikat dengan urease, sehingga sebelum dan sesudah penghambatan, respon sensor dapat dioptimalkan. Perbedaan intensitas pengukuran sebelum dan sesudah penghambatan dapat dibaca pada sinyal optimum. Waktu inhibisi oleh logam $\mathrm{Hg}(\mathrm{II})$ dengan menambahkan larutan ion $\mathrm{Hg}(\mathrm{II})$ selama 7 menit, penghambatan ion $\mathrm{Hg}$ (II) telah dioptimalkan untuk pengukuran ini.

Penentuan jenis reaksi inhibisi enzim dilakukan dengan membuat diagram LineweaverBurk dengan memplotkan $1 /[\mathrm{S}]$ versus $1 / \mathrm{V}$. Nilai $\mathrm{V}$ merupakan fungsi pengubahan substrat terhadap waktu untuk membentuk produk, dan pengubahan ini diukur berdasarkan selisih intensitas yang terbaca oleh amperometri. Berdasarkan perhitungan dari persamaan Lineweaver-Burk didapatkan bahwa nilai $\mathrm{K}_{\mathrm{m}}=0.115 \mathrm{mM}$ dan $\mathrm{V}_{\max }=0,02 \Delta \mu \mathrm{A} / \mathrm{s}$ sebelum penambahan inhibitor, sedangkan sesudah penambahan inhibitor menunjukkan nilai $\mathrm{K}_{\mathrm{m}}=0.126$ $\mathrm{mM}$ dan $\mathrm{V}_{\max }=0,02 \Delta \mu \mathrm{A} / \mathrm{s}$. Nilai $\mathrm{K}_{\mathrm{m}}$ yang diperoleh terlihat cenderung meningkat setelah penambahan inhibitor, hal ini disebabkan substrat dan inhibitor saling bersaing dalam menyerang sisi aktif enzim. Pada sistem ini energi ikat substrat sama dengan energi ikat inhibitor, sebagian enzim akan berikatan dengan substrat dan sebagian lagi akan berikatan dengan inhibitor. Nilai penghambatan yang dihasilkan sebanding dengan konsentrasi dan afinitas relatif keduanya (substrat dan inhibitor) sehingga nilai penghambatannya dapat diatasi dengan menaikkan konsentrasi substrat. Pada penambahan konsentrasi substrat yang tinggi, inhibitor tidak mampu lagi bersaing dengan substrat karena semua situs aktif enzim akan ditempati oleh substrat. Pada kondisi ini diperoleh nilai $\mathrm{V}_{\max }$, kecepatan reaksi hanya tergantung pada molekul enzim yang tidak terhambat dan tidak dipengaruhi inhibitor. Oleh karenanya dalam penelitian ini didapatkan nilai $\mathrm{V}_{\max }$ yang hampir sama dengan ketika belum ditambahkan inhibitor dalam sistem. Interaksi sistem urease dengan inhibitor $\mathrm{Hg}(\mathrm{II})$ adalah penginhibisian secara reversibel nonkompetitif.

Pada kurva kalibrasi ion logam $\mathrm{Hg}(\mathrm{II})$ (Gambar 1) dihasilkan koefisien determinasi $\mathrm{R}^{2}=$ 0,9747 dan harga $\mathrm{b}$ yang positif, jadi didapatkan koefisien korelasi $\mathrm{r}=+0,9888$. Hal ini berarti $\mathrm{R}^{2 \square} \approx 1$ (kurva yang dihasilkan adalah linier). Harga $r$ yang positif menunjukkan besarnya kenaikan jumlah ion logam $\mathrm{Hg}$ (II) yang terinhibisi meningkat sebanding dengan kenaikan konsentrasinya. Korelasi linier yang dihasilkan ini terjadi pada range konsentrasi ion logam $\mathrm{Hg}(\mathrm{II})$ antara 40-90 ppb. IC $_{50}$ didapatkan sekitar 50 ppb, jadi pada konsentrasi ini 50\% aktivitas 
enzim terinhibisi. Dari perhitungan diperoleh harga Ki sebesar 31,25 ppb, sehingga dapat dikatakan bahwa afinitas $\mathrm{Hg}(\mathrm{II})$ terhadap urease sebesar 31,25 ppb.

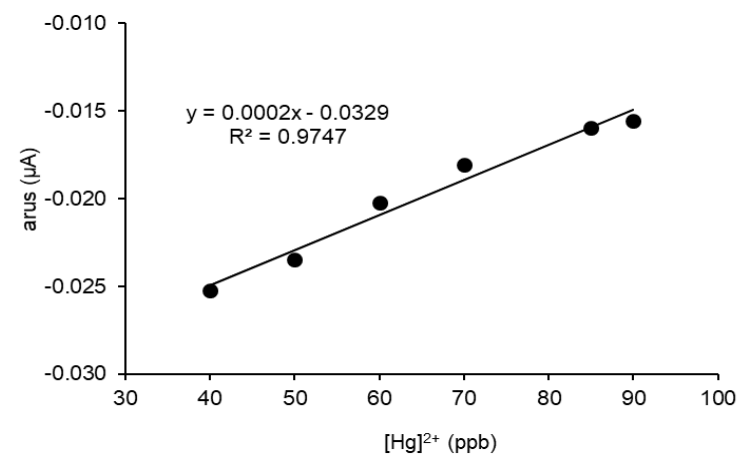

Gambar 1. Kurva kalibrasi respon arus terhadap konsentrasi ion logam $\mathrm{Hg}$ (II)

Batas deteksi merupakan konsentrasi terkecil dari analit (ion logam berat) yang dapat diukur oleh alat. Berdasarkan kurva kalibrasi yang diperoleh, perhitungan batas deteksi ditentukan dengan menggunakan konsentrasi analit ketika menginhibisi enzim sebesar $10 \%$. Inhibisi $10 \%$ ini dipilih karena menganggap bahwa pada $\mathrm{I}_{10 \%}$ selisih intensitas sebelum dan sesudah inhibisi dapat diamati dengan selang kepercayaan $90 \%$. Batas deteksi diperoleh dari perhitungan $\mathrm{I}_{10 \%}$ berdasarkan kurva kalibrasi adalah sebesar 66,45 ppb untuk $\mathrm{Hg}(\mathrm{II})$.

Repeatibilitas merupakan tingkat keterulangan suatu hasil pengukuran biosensor amperometri. Hasil pengukuran yang memiliki keterulangan tinggi dikatakan memiliki kepresisian yang tinggi. Repeatibilitas dihitung menggunakan koefisien variasi $\left(\mathrm{K}_{\mathrm{v}}\right)$. Koefisien variasi menyatakan persentase dispersi relatif suatu hasil pengukuran, semakin besar koefisien variasi maka tingkat keseragaman data akan semakin kecil dan hal ini dapat dikatakan bahwa presisinya juga menjadi rendah. Berdasarkan pengukuran menggunakan software PS.Trace 4.2 diperoleh relatif standar deviasi (memiliki arti yang sama dengan nilai $\mathrm{K}_{\mathrm{v}}$ ) sebesar 0,8 $\%$ untuk $\mathrm{Hg}$. Harga $\mathrm{K}_{\mathrm{v}}$ yang diperoleh ini sangat kecil $(<5 \%)$, sehingga dapat disimpulkan bahwa data yang diperoleh memiliki tingkat kepresisian atau repeatibilitas yang tinggi.

Biosensor yang berbasis imobilisasi enzim memiliki keuntungan bisa digunakan ulang setelah dipakai dengan cara direaktivasi. Biosensor yang mengandung urease immobil setelah mengalami inhibisi ion logam berat dapat direaktivasi dengan mengalirkan EDTA $1 \mathrm{mM}$ [7]. Waktu hidup atau pemakaian berulang dari biosensor ini dilihat dari penurunan aktivitas enzim akibat adanya inhibisi selama satu minggu. Selain disebabkan oleh inhibisi logam, enzim immobil juga mengalami penurunan aktivitas selama penyimpanan. Salah satu cara untuk mencegah penuruan aktivitas ini adalah urease immobil disimpan pada suhu $4{ }^{\circ} \mathrm{C}$ ketika tidak digunakan. Tetapi bila biosensor yang mengandung urease immobil ini ditempatkan pada suhu $27{ }^{\circ} \mathrm{C}$, maka aktivitas enzim tersebut akan hilang sama sekali. Data penurunan respon biosensor terhadap urea akibat adanya inhibisi ion logam berat berdasarkan hasil perhitungan dengan adanya inhibisi, enzim mengalami penurunan aktivitas sebesar $7,69 \%$ setelah 4 kali pemakaian dan mengalami penurunan aktivitas sebesar 9,94\% setelah 5 kali pemakaian. Dari hasil ini maka dapat diambil kesimpulan bahwa penggunaan biosensor urease untuk pendeteksian ion logam berat ini adalah 5 kali pemakaian setelah direaktivasi, karena dari hasil perhitungan enzim mengalami penurunan aktivitas $<10 \%$ akibat adanya inhibisi. Hal ini menunjukkan bahwa selang kepercayaan terhadap pengukuran inhibisi enzim sebesar 90\%. Inhibisi urease oleh logam berat bisa mengurangi aktivitas katalitiknya karena logam berat bersaingan dengan susbstrat dalam menyerang sisi aktif urease sehingga laju pembentukan produk menjadi terhambat. Aktivitas enzim dalam biosensor amperometri yang telah terinhibisi dapat dikembalikan secara mudah dan efisien dengan cara mereaktivasi. Reaktivasi dimaksudkan agar biosensor dapat digunakan kembali untuk pengukuran selanjutnya sehingga penggunaan enzim lebih ekonomis. Inhibisi enzim oleh logam berat bersifat reversibel sehingga dapat direaktivasi dengan mudah dengan cara menarik logam berat yang terinhibisi tersebut dengan menggunakan EDTA 1 $\mathrm{mM}$.

Salah satu aspek penting dalam mengukur performa biosensor adalah dengan menguji selektivitasnya terhadap beberapa pengganggu (interferen). Selektivitas biosensor ditentukan dengan menambahkan jumlah yang berbeda dari ion yang berpotensi mengganggu yang umumnya ditemukan dalam sampel air di lingkungan, seperti $\mathrm{Pb}(\mathrm{II}), \mathrm{Cu}$ (II), Cd(II) dan $\mathrm{Ag}(\mathrm{I})$ pada $100 \mu \mathrm{g} / \mathrm{L}$ [12]. Data respon biosensor terhadap interferen menunjukkan bahwa nilai relatif yang diperoleh dari penghambatan ion logam lainnya (Pb(II), $\mathrm{Cu}(\mathrm{II})$, dan $\mathrm{Cd}(\mathrm{II})$ ), dibandingkan dengan sinyal blanko (tanpa hambatan) sangat kecil $(<5 \%)$, menunjuk kan bahwa ion logam berat ini pada konsentrasi ini $(100 \mu \mathrm{g} / \mathrm{L})$ tidak secara signifikan menyebabkan gangguan. Namun, hanya ion $\mathrm{Ag}(\mathrm{I})$ yang menyebabkan gangguan yang relatif besar pada konsentrasi ini dibandingkan dengan ion logam berat lainnya yang diuji. Hal ini disebabkan ion $\operatorname{Ag}(\mathrm{I})$ sama dengan ion $\mathrm{Hg}$ (II) yang akan mempengaruhi aktivitas enzim penghambatan, terutama pada konsentrasi tinggi. Ion $\mathrm{Ag}(\mathrm{I})$ memiliki potensi sebagai ion pengganggu pada biosensor amperometri $\mathrm{Hg}$ (II), hal ini dikarenakan ion $\mathrm{Ag}(\mathrm{I})$ dan $\mathrm{Hg}(\mathrm{II})$ dalam konsep HSAB merupakan asam lemah.

Respon biosensor serat optik dan amperometri pada pemonitoran $\mathrm{Hg}$ (II) dalam sistem larutan telah dikaji pada kondisi optimum. Langkah penting selanjutnya adalah menentukan karakteristik analitis dari kinerja biosensor serat optik dan amperometri. Sebagai perbandingan, kinerja analitis seperti rentang linier dan batas deteksi dari biosensor yang diusulkan dan biosensor berbasis enzim lainnya yang dilaporkan dalam literatur semuanya diringkas dalam Tabel 2 . 
Rentang linear dari biosensor pada kajian ini memiliki kisaran konsentrasi $\mathrm{Hg}(\mathrm{II})$ relatif rendah. Batas deteksi untuk $\mathrm{Hg}$ (II) yang diperoleh dari biosensor penelitian ini lebih rendah daripada oleh biosensor yang dilaporkan sebelumnya. Hasil ini menunjukkan bahwa biosensor yang diusulkan adalah platform yang sangat baik untuk deteksi sensitif $\mathrm{Hg}$ (II).

Tabel 2. Perbandingan kinerja untuk deteksi $\mathrm{Hg}(\mathrm{II})$ oleh biosensor berbasis inhibisi enzim

\begin{tabular}{|c|c|c|c|c|c|}
\hline Enzim & Matriks immobilisasi & $\begin{array}{l}\text { Biosensor } \\
\text { transduser }\end{array}$ & $\begin{array}{c}\text { Rentang } \\
\text { Linear } \\
\mu \mathrm{g} / \mathrm{mL}\end{array}$ & $\begin{array}{c}\text { Limit } \\
\text { deteksi } \\
\mu \mathrm{g} / \mathrm{mL}\end{array}$ & Pustaka \\
\hline urease & PEC alginat-kitosan & amperometri & $0.04-0.09$ & 0.066 & hasil penelitian \\
\hline urease & PEC alginat-kitosan & serat optik & $0.05-0.5$ & 0.012 & [13] \\
\hline urease & poly(vinylferrocenium) & amperometri & $2.5-115$ & 2.0 & {$[8]$} \\
\hline $\begin{array}{l}\text { urease } \\
\& A C h e\end{array}$ & TMOS/ FITC-dextran & $\begin{array}{l}\text { fluoresense } \\
\text { optik sensor }\end{array}$ & $0.2-20$ & 0.2 & [14] \\
\hline urease & $\begin{array}{l}\text { tetramethyl orthosilicate } \\
\text { (TMOS) }\end{array}$ & konduktometri & $1-100$ & $1-100$ & {$[15]$} \\
\hline
\end{tabular}

\section{KESIMPULAN}

Biosensor amperometri $\mathrm{Hg}(\mathrm{II})$ berbasis membran urease/alginat-kitosan termodifikasi pada screen printed karbon elektroda memiliki kondisi optimum pengukuran pada potensial kerja $-0,15 \mathrm{~V}$, $\mathrm{pH} 7$, konsentrasi substrat $75 \mathrm{mM}$, waktu respon 8 detik, waktu inhibisi 7 menit dan suhu $25{ }^{\circ} \mathrm{C}$. Hasil karakterisasi biosensor amperometri $\mathrm{Hg}(\mathrm{II})$ yaitu range konsentrasi ion logam $\mathrm{Hg}$ (II) antara 40-90 ppb dengan batas deteksi $\mathrm{I}_{10 \%}$ adalah $66.45 \mathrm{ppb}$ dan koefisien variansi (Kv) sebesar $0,8 \%$, serta reaktivasi pemakaian ulang sebanyak 5 kali. Ion logam berat lain yang diinhibisikan pada urease terimobil mengikuti penurunan respon biosensor berpotensi sebagai interferen ion $\mathrm{Ag}(\mathrm{I})>\mathrm{Cu}(\mathrm{II})>\mathrm{Co}(\mathrm{II})>\mathrm{Pb}(\mathrm{II})$.

\section{DAFTAR PUSTAKA}

1. Szkoda, J., Żmudzki, J. A. N., \& Grzebalska, A. (2006). Determination of Total Mercury in Biological Material by Atomic Absorption Spectrometry Method, Mercury, 45, 363-366.

2. Nixon, D. E., Burritt, M. F., \& Moyer, T. P. (1999). The Determination of Mercury in Whole Blood and Urine by Inductively Coupled Plasma Mass Spectrometry, Spectrochim. Acta Part B: Atomic Spec., 54(8), 1141-1153.

3. Pujol, L., Evrard, D., Groenen-Serrano, K., Freyssinier, M., Ruffien-Cizsak, A., \& Gros, P. (2014). Electrochemical Sensors and Devices for Heavy Metals Assay in Water: the French Groups' Contribution., Front. Chem., 2(4), 1-24.

4. Elsebai, A. B., Ghica, M. E., Abbas, N., \& Brett, C. M. A. (2017). Catalase Based Hydrogen Peroxide Biosensor for Mercury Determination by Inhibition Measurements, J. Hazard. Mater., 340, 344-350.

5. Turdean, G. L. (2011). Design and evelopment of Biosensors for the Detection of Heavy Metal Toxicity, Int. J. Electrochem., 2011, 1-15.

6. Krawczynski, T., \& Krawczyk, V. (1998). Analytical Applications of Inhibition of Enzymatic Reactions, Chem. Anal., 43, 135-158.

7. Kuswandi, B. (2003). Simple Optical Fibre Biosensor Based on Immobilised Enzyme for
Monitoring of Trace Heavy Metal Ions, Anal. Bioanal. Chem., 376(7), 1104-1110.

8. Kuralay, F., Ozy, H., \& Y1ldı, A. (2007). Inhibitive Determination of $\mathrm{Hg}^{2+}$ Ion by $\mathrm{An}$ Amperometric Urea Biosensor Using Poly(Vinylferrocenium) Film, Enzym. Microb. Technol., 40, 1156-1159.

9. Hermanto, D., Mudasir, M., Siswanta, D., \& Kuswandi, B. (2019a). Synthesis of AlginateChitosan Polyelectrolyte Complex (PEC) Membrane and Its Physical-Mechanical Properties. J. Sci. Appl. Chem., 22(1), 11-16.

10. Yabuki, S. (2011). Polyelectrolyte Complex Membranes for Immobilizing Biomolecules, and Their Applications to Bio-analysis, Anal. Sci. 27(7), 695-702.

11. Hermanto, D., Kuswandi, B., Siswanta, D., \& Mudasir, M. (2019b). Inhibitive Determination of $\mathrm{Hg}(\mathrm{II})$ in Aqueous Solution Using Urease Amperometric Biosensor. Ind. J. Chem., 19(3), 786-795.

12. Azmi, N. E., Abdullah, J., Ahmad, M., Sidek, H., Heng, L. Y., \& Rahman, S. A. (2012). An Optical Based Biosensor for the Determination of Ammonium in Aqueous Environment, Am. J. Anal. Chem., 3(5), 364-370.

13. Hermanto, D., Mudasir, M., Siswanta, D., \& Kuswandi, B. (2019c). Pemanfaatan Kompleks Polielektrolit sebagai Matriks untuk Imobilisasi Urease dan Aplikasinya sebagai Membran Biosensor Monitor Hg(II), Al Kimia, 7(1), 1-9.

14. Tsai, H., \& Doong, R. (2005). Simultaneous Determination of $\mathrm{pH}$, Urea, Acetylcholine and Heavy Metals Using Array-Based Enzymatic Optical Biosensor, Biosens. Bioelectron., 20,1796-1804.

15. Lee, S., \& Lee, W. (2002). Determination of Heavy Metal Ions Using Conductometric Biosensor Based on Sol-Gel-Immobilized Urease, Bull. Korean Chem. Soc. 23(8), 1169-1172. 